\title{
Impact of Zinc on Gasification Reaction and Post-Reaction Strength of Ferro-coke
}

\author{
LI Peng 1, a, Liu Wei 1, b, BI Xuegong 1, c, Wang Yayu 1, d, \\ Zhou Jindong ${ }^{1,}$ e , Shi Shizhuang ${ }^{2, f}$
}

1- State Key Laboratory for Refractory Materials and Metallurgy, Wuhan University of Science and Technology, Wuhan 430081, Hubei, China;

2- Key Laboratory for Ferrous Metallurgy and Resources Utilization of Ministry of Education

, Wuhan University of Science and Technology, Wuhan 430081, Hubei, China;

3- Key Laboratory for Coal Conversion and Advanced Carbon Materials of Hubei Province, Wuhan University of Science and Technology, Wuhan 430081, Hubei, China.

a-676827382@qq.com, b-595320315@qq.com,c-1575595611@qq.com,d-1145724398@qq.com, e-402535949@qq.com, f-shisz1956@126.com

Key words: ferro-coke; zinc; gasification reaction; thermal properties; shrinking-core model

Abstract: Ferro-coke is an iron-containing novel kind of coke, to clarify its behavior of $\mathrm{CO}_{2}$ gasification under $\mathrm{Zn}$ recirculating condition in the blast furnace is very important for its practical application in BF production. In this paper, the weight loss of ferro-coke was determined with a thermogravimetric balance, the variation in exhaust gas composition at several different temperatures were measured with a gas analyzer. The results revealed that zinc has catalytic effect on $\mathrm{CO}_{2}$ gasification in respect to the decrease in starting gasification temperature and the increase of burning-off degree. And also for ferro-coke, the reactivity increased while the post-reaction strength decreased along with the zinc content increasing. Generally speaking, the impact of zinc on ferro-coke thermal properties is weaker than potassium.

\section{INTRODUCTION.}

Ferro-coke is a special coke prepared by carbonizing the mix of iron ores and cokemaking coals. Due to higher Fe content, its reactivity with $\mathrm{CO}_{2}$ gas is much higher than normal coke. ${ }^{[1-2]} \mathrm{By}$ feeding ferro-coke, normally together with iron ores, the thermal reserve zone temperature will decline, as a result, the indirect reduction degree will raise and RAR will be decreased. ${ }^{[3-4]}$ This is the reason why ferro-coke is considered a promising novel burden material for BF ironmaking process. Two processes have been tried for ferro-coke production, i.e. the traditional slot-type coke oven process ${ }^{[5]}$ and the briquetting/shaft process. ${ }^{[6]}$ It was reported that in Japan research and development for ferro-coke will be continued in the consecutive 2018 FY.

As is well known there is an accumulation during recycling of zinc in the blast furnace, ${ }^{[7-8]}$ causing many problems on BF operation such as worsening of the metallurgical properties of burden materials, formation of scaffold and inactive zone near the wall, ${ }^{[9]}$ abnormal gas distribution, etc. The control level of zinc charged into the furnace is $0.10 \sim 0.20 \mathrm{~kg}$ per ton hot metal in China, depending on BF effective volume.

It is obviously required to understand the impact of zinc accumulation on the thermal properties of ferro-coke for the provision of control level of zinc charged into the furnaces fed with ferro-coke. Recent years in China, some laboratory studies on the impact of zinc on the properties of traditional coke have been conducted, including a comprehensive investigation on the evolution of structural order, microstructure and mineral matter of metallurgical coke reported by Li et al. ${ }^{[10]}$

In this paper, the impact of zinc on $\mathrm{CO}_{2}$ gasification and the thermal properties of ferro-coke were investigated in laboratory with an approach of zinc acetate aqueous solution soaking and 
boiling for adding zinc to the samples.

\section{EXPERIMENTAL STUDY.}

\section{Experimental Samples.}

Traditional coke and ferro-coke samples were prepared in the $6 \mathrm{~kg}$ experimental coke oven of Wuhan University of Science and Technology, the industrial coal blends from Wuhan Allied Cokemaking Company of Pingmei and Wugang were directly used for the traditional coke preparation while for the ferro-coke preparation $10 \%$ Canadian iron concentrate was mixed into the industrial coal blends.

The properties of the coal blend and iron concentrate are respectively presented in Tables 1 and 2. The stamping charge technique was applied to control the bulk density of coal charge at about 1.1 $\mathrm{kg} / \mathrm{cm}^{3}$ for the purpose of attaining coke products with higher post-reaction strength. To quench the discharged coke with nitrogen gas is desirable, but for convenience, water was applied for quenching coke in this work. The prime properties of coke samples are shown in Tables 3 and 4.

Table 1 Basic properties of coal blend

\begin{tabular}{cccccccc}
\hline $\begin{array}{c}\mathrm{M}_{\mathrm{ad}} \\
{[\mathrm{mass} \%]}\end{array}$ & $\begin{array}{c}\mathrm{A}_{\mathrm{d}} \\
{[\mathrm{mass} \%]}\end{array}$ & $\begin{array}{c}\mathrm{V}_{\mathrm{d}} \\
{[\mathrm{mass} \%]}\end{array}$ & $\begin{array}{c}\mathrm{S}_{\mathrm{t.d}} \\
{[\mathrm{mass} \%]}\end{array}$ & $\mathrm{G}$ & $\lg M F$ & $\begin{array}{c}\mathrm{Y} \\
{[\mathrm{mm}]}\end{array}$ & $\lg M F^{\prime}$ \\
\hline 1.70 & 9.41 & 27.95 & 0.818 & 86.38 & 3.01 & 16 & 3.12 \\
\hline
\end{tabular}

Note: $M_{a d}, A_{d}, V_{d}$ and $S_{t . d}$ is respectively the moisture, ash, volatile matter and total sulfur content; $G$ is the caking property index, $Y$ is the thickness of colloids layer, $\lg M F$ is (Gieseler) fluidity index converted from $\mathrm{G}, \lg M F{ }^{\prime}$ is (Gieseler) fluidity index converted from $\mathrm{Y}$.

Table 2 Chemical composition of Canadian iron concentrate

\begin{tabular}{ccccccccccc}
\hline Content & $\mathrm{T} . \mathrm{Fe}$ & $\mathrm{FeO}$ & $\mathrm{SiO}_{2}$ & $\mathrm{Al}_{2} \mathrm{O}_{3}$ & $\mathrm{CaO}$ & $\mathrm{MgO}$ & $\mathrm{S}$ & $\mathrm{P}$ & $\mathrm{K}_{2} \mathrm{O}$ & $\mathrm{Na}_{2} \mathrm{O}$ \\
\cline { 2 - 10 } & 66.50 & 0.82 & 3.97 & 0.27 & 0.08 & 0.01 & 0.022 & 0.020 & 0.001 & 0.001 \\
\hline
\end{tabular}

Table 3 Basic properties of the coke samples

\begin{tabular}{ccccccccc}
\hline Sample & $\begin{array}{c}\text { Metallization } \\
\text { rate [\%] }\end{array}$ & $\begin{array}{c}\mathrm{A}_{\mathrm{d}} \\
{[\mathrm{mass} \%]}\end{array}$ & $\begin{array}{c}\mathrm{S}_{\mathrm{t.d}} \\
{[\mathrm{mass} \%]}\end{array}$ & $\begin{array}{c}\mathrm{V}_{\mathrm{d}} \\
{[\mathrm{mass} \%]}\end{array}$ & $\begin{array}{c}\rho_{a} \\
{\left[\mathrm{~g} \cdot \mathrm{cm}^{-3}\right]}\end{array}$ & $\begin{array}{c}\rho_{t} \\
{\left[\mathrm{~g} \cdot \mathrm{cm}^{-3}\right]}\end{array}$ & $\begin{array}{c}P_{t} \\
{[\mathrm{vol} \%]}\end{array}$ & $\begin{array}{c}P_{a} \\
{[\mathrm{vol} \%]}\end{array}$ \\
\hline $\begin{array}{c}\text { Traditional } \\
\text { coke }\end{array}$ & 45.00 & 13.44 & 0.56 & 1.72 & 1.02 & 1.96 & 47.76 & 38.03 \\
Ferro-coke & 57.98 & 25.47 & 0.61 & 1.33 & 1.07 & 2.12 & 48.96 & 40.46 \\
\hline
\end{tabular}

Note: $\rho_{a}$ is the apparent density, $\rho_{t}$ is the true density; $P_{t}$ is the total porosity, $P_{a}$ is the open porosity.

Table 4 Chemical composition of the coke samples [mass\%]

\begin{tabular}{ccccccccc}
\hline Sample & M.Fe & T.Fe & $\mathrm{K}_{2} \mathrm{O}$ & $\mathrm{CaO}$ & $\mathrm{SiO}_{2}$ & $\mathrm{Al}_{2} \mathrm{O}_{3}$ & $\mathrm{MgO}$ & $\mathrm{Fe}_{2} \mathrm{O}_{3}$ \\
\hline $\begin{array}{c}\text { Traditional } \\
\text { coke }\end{array}$ & 0.27 & 0.60 & 0.10 & 0.52 & 5.33 & 9.87 & 0.21 & 1.90 \\
Ferro-coke & 5.23 & 9.02 & 0.081 & 0.51 & 6.14 & 5.06 & 0.13 & 12.27 \\
\hline
\end{tabular}

$\mathrm{Zn}\left(\mathrm{CH}_{3} \mathrm{COO}\right)_{2} \cdot 2 \mathrm{H}_{2} \mathrm{O}$ easily dissolves in water, produces anhydrous zinc acetate at temperatures below $200{ }^{\circ} \mathrm{C}$, and completely decomposes into $\mathrm{ZnO}$ at temperatures beyond $370{ }^{\circ} \mathrm{C}$. Coke samples with varied $\mathrm{ZnO}$ addition were obtained by regulating the concentration of zinc acetate solution and/or the boiling time. The zinc addition scheme listed in Table 5 was accepted in this work.

\section{Starting Reaction Temperature Measurement.}

The experimental apparatus was a custom-made vertical tubular electric furnace with an isothermal zone of $70 \mathrm{~mm}$ in height. It usually worked at a temperature of $1100^{\circ} \mathrm{C}$, the error was $\pm 1^{\circ} \mathrm{C}$. The reaction tube (inner diameter $60 \mathrm{~mm}$ ) was made of quartz glass and alumina crucibles were used in the tests. The flow rate of reaction gases was controlled by LZ-A-15 version intelligent metal tube float flowmeters. An electronic balance of $0.001 \mathrm{~g}$ in precision was used for a continuous 
weighing. The real time data from the balance were recorded by a computer. The $\mathrm{CO}$ and $\mathrm{CO}_{2}$ concentrations in exhaust gases were analyzed by the Gas-board 3100 version infrared gas analyzer (Wuhan Tetragon Tech \& Sci. Co.).

Table 5 Scheme of zinc addition of coke samples

\begin{tabular}{ccccc}
\hline Experiment & Run no. & $\begin{array}{c}\text { Zinc acetate } \\
{[\text { mass\%] }}\end{array}$ & $\begin{array}{c}\text { Boiling time } \\
{[\mathrm{min}]}\end{array}$ & $\begin{array}{c}\text { ZnO addition } \\
{[\text { mass\%] }}\end{array}$ \\
\hline $\begin{array}{c}\text { Starting reaction } \\
\text { temperature }\end{array}$ & $\mathrm{C}-1$ & - & - & 0 \\
measurement of & $\mathrm{C}-2$ & 5 & 30 & 0.85 \\
ferro-coke & $\mathrm{C}-3$ & 10 & 30 & 1.63 \\
\hline C-4 & F-1 & - & 30 & 2.23 \\
phermal & F-2 & 10 & - & 0 \\
measurement of & F-3 & 10 & 20 & 0.23 \\
ferro-coke & F-4 & 10 & 30 & 1.41 \\
\hline
\end{tabular}

Note: C-1 and F-1 are samples without zinc addition; F-1 F-5 are samples of ferro-coke for thermal properties measurement.

The starting gasification temperature affects the size of the indirect reduction zone and is of a great importance for blast furnace operation. The weight of a ferro-coke sample dried for $2 \mathrm{~h}$ was $100 \pm 0.1 \mathrm{~g}$. It was added with zinc and then put into the furnace. The temperature was raised to $500^{\circ} \mathrm{C}$ at $10^{\circ} \mathrm{C} / \mathrm{min}$ under the protection of nitrogen gas at a flow rate of $0.1 \mathrm{~m}^{3} / \mathrm{h}$. After this, $\mathrm{N}_{2}$ was switched to $\mathrm{CO}_{2}\left(0.18 \mathrm{~m}^{3} / \mathrm{h}\right)$, the gas analyzer was simultaneously turned on to analyze $\% \mathrm{CO}$ in the exhaust gases. When temperature reached the stated value, it was stopped to heat and started to introduce $\mathrm{N}_{2}$ for cooling. The temperature where $\% \mathrm{CO}$ in waste gases reached $1 \mathrm{vol} \%$ was defined as the starting gasification temperature in this work.

\section{Reactivity and Post-Reaction Strength Measurement.}

The amount of a sample required in the Particles Coke Method (Chinese standard: GB/T 4000-1966) is large and therefore in this paper the Tablets Coke Method (GB 220-77) was utilized for measuring the thermal properties of coke. The size of coke sample is 4 to $6 \mathrm{~mm}$ and the total weight was $15 \pm 0.02 \mathrm{~g}$. The sample was exposed to $1100^{\circ} \mathrm{C}$ and pure $\mathrm{CO}_{2}$ gas $\left(0.18 \mathrm{~m}^{3} / \mathrm{h}\right)$ for $2 \mathrm{~h}$. The reactivity index and the post-reaction strength index are respectively defined in Eqs. (1) and (2):

$$
\begin{aligned}
& \operatorname{CRI}_{\mathrm{TCM}}(\%)=\left(m-m_{1}\right) / m \times 100 . \\
& \operatorname{CSRR}_{\mathrm{TCM}}(\%)=m_{2} / m \times 100 .
\end{aligned}
$$

where $m$ is the coke mass prior reaction, $\mathrm{g} ; m_{1}$ is the coke mass after reaction, $\mathrm{g} ; m_{2}$ is the mass of coke larger than $3 \mathrm{~mm}$ after reaction, g; CRI $\mathrm{TCM}_{\mathrm{T}}$ is reactivity by the Tablets Coke Method, \%; $\mathrm{CSR}_{\mathrm{TCM}}$ is post-reaction strength by the Tablets Coke Method, \%.

\section{RESULTS AND DISCUSSIONS}

\section{Impact of Zinc on Starting Gasification Temperature of Ferro-Coke.}

It can be seen from Fig. 1 that with temperature increasing the $\mathrm{CO}$ content gradually increased. As the $\mathrm{CO}$ content reached about $1 \%$, the rising trend in the curves became noticeable. For this reason, the temperature where the $\mathrm{CO}$ content is equal to $1 \%$ is defined as the starting gasification temperature in this paper.

The starting gasification temperature of five ferro-cokes with different $\mathrm{ZnO}$ addition were evaluated according to Fig. 1, the results are depicted in Fig. 2. The starting gasification temperature of original ferro-coke $\mathrm{C}-1$ was $683^{\circ} \mathrm{C}$, while the starting gasification temperature of $\mathrm{C}-2$, C-3, and C-4 were respectively $637^{\circ} \mathrm{C}, 632^{\circ} \mathrm{C}$ and $630^{\circ} \mathrm{C}$, and their extents of decrease were respectively $46^{\circ} \mathrm{C}, 51^{\circ} \mathrm{C}$ and $53^{\circ} \mathrm{C}$, demonstrating $\mathrm{Zn}$ decreased the starting gasification temperature of ferro-coke. Also can be seen in Fig. 1 when the $\mathrm{ZnO}$ addition did not exceed $0.85 \%$, 
the starting gasification temperature decreased sharply with increasing the $\mathrm{ZnO}$ addition, and that when the $\mathrm{ZnO}$ addition was beyond $0.85 \%$, the tendency of decrease obviously became gentle.

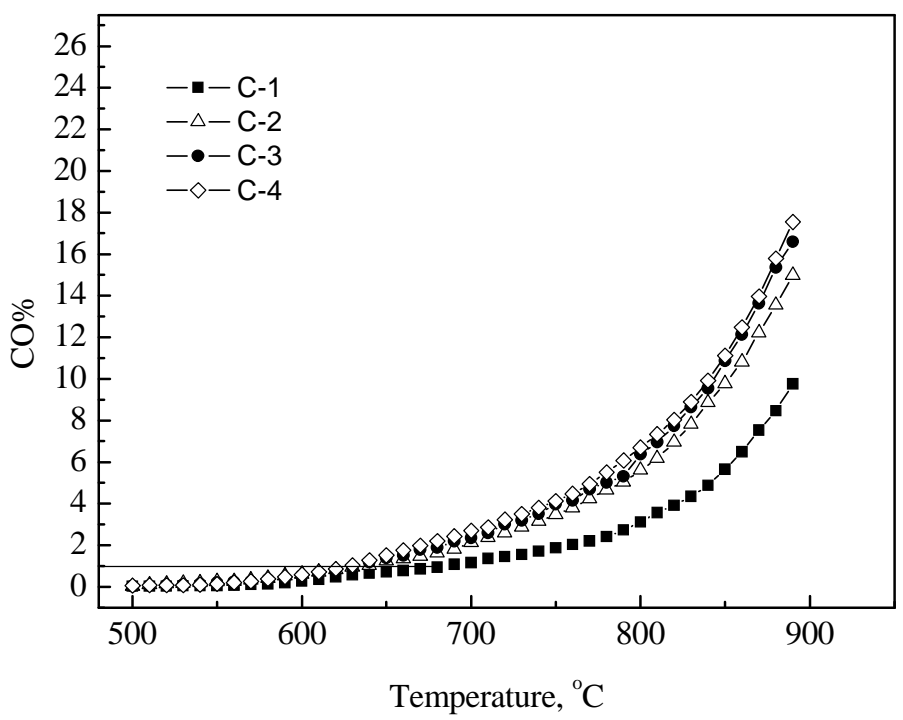

Fig. 1 Relationship between $\mathrm{CO}$ content in waste gases and temperature

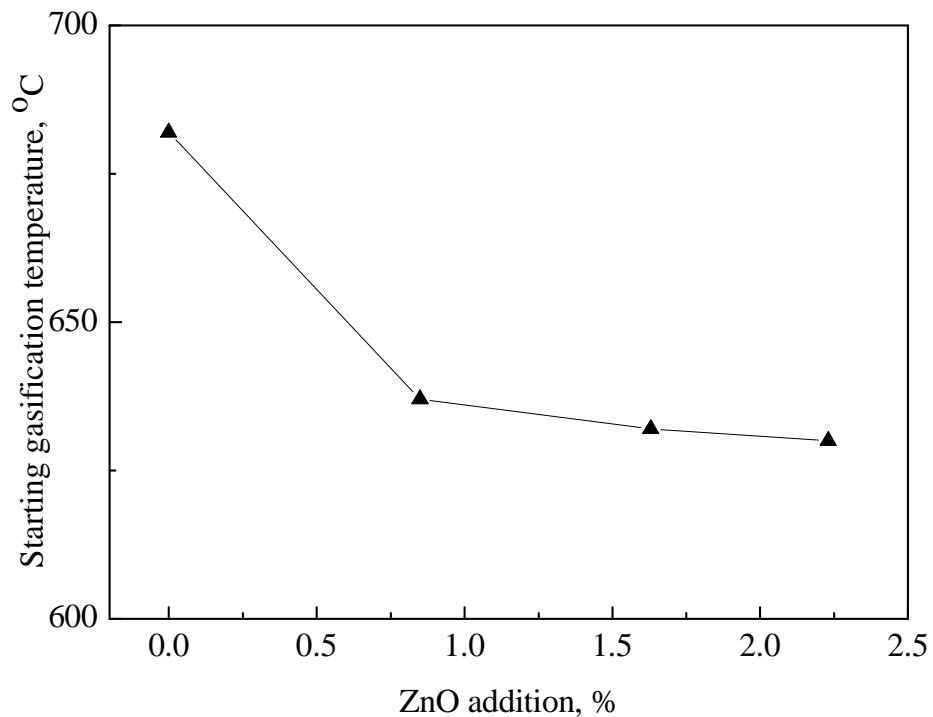

Fig. 2 Relationship between $\mathrm{ZnO}$ addition and starting gasification temperature of ferro-coke

Influence of Zinc Addition on Reactivity and Post-Reaction Strength of Ferro-Coke.

The reactivity and post-reaction strength of ferro-coke were measured with use of the Tablets Coke Method, the results are shown in Fig. 3.

It is known from Fig. 3 that for ferro-coke, CRITCM apparently increased while CSRTCM apparently decreased with the $\mathrm{ZnO}$ addition increasing. When the $\mathrm{ZnO}$ addition was $0 \%, 0.23 \%$, $0.96 \%, 1.41 \%$ and $2.27 \%$, the CRI $\mathrm{T}_{\mathrm{TCM}}$ was respectively $28.37 \%, 28.89 \%, 31.89 \%, 34.58 \%$ and $36.29 \%$ while the CSR $\mathrm{TCM}$ was respectively $64.62 \%, 64.05 \%, 61.05 \%, 58.16 \%$ and $55.77 \%$, stating the reactivity of ferro-coke increases and the post-reaction strength of ferro-coke decreases with increasing $\mathrm{ZnO}$ addition. 


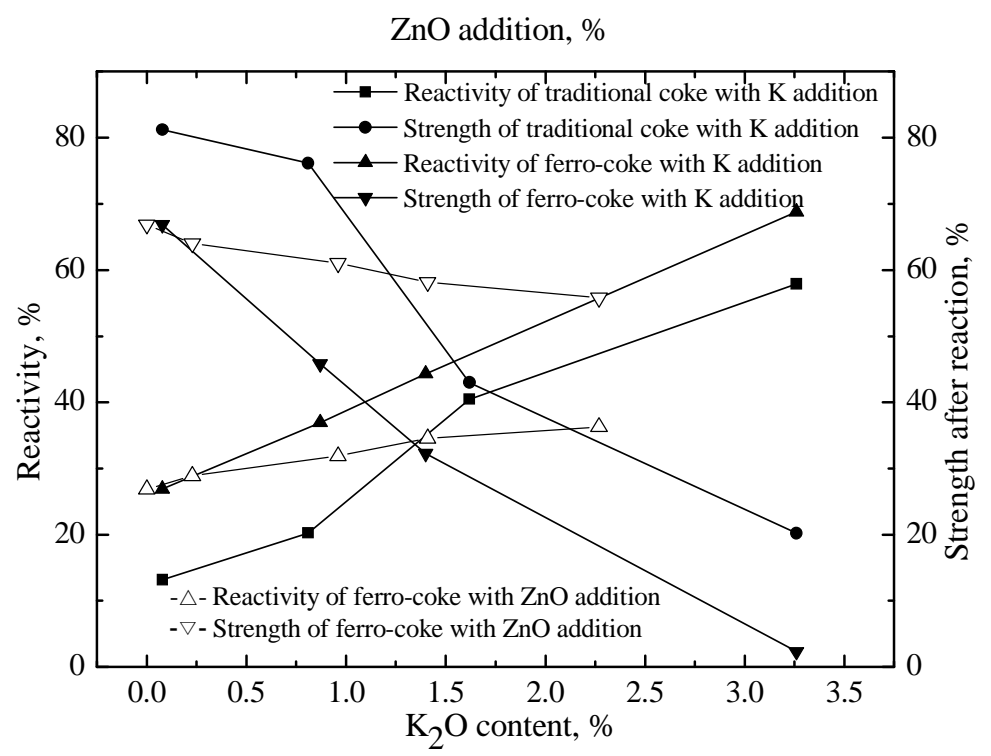

Fig. 3 Effect of $\mathrm{Zn}$ and $\mathrm{K}$ on thermal properties of traditional coke and ferro-coke

As can be seen in Fig. 4 that there is a good negative linear relation between CSR TCM $_{\text {and }}$ $\mathrm{CRI}_{\mathrm{TCM}}$ for ferro-coke, just like traditional coke. For zinc addition, the declining rate of CSR $\mathrm{TCM}_{\text {is }}$ $1.093 \%$ for every $1 \%$ increase of $\mathrm{CRI}_{\mathrm{TCM}}$, smaller than that for $\mathrm{K}_{2} \mathrm{O}$ addition $(1.498 \%)$, ${ }^{[12]}$ meaning the degree of damage caused by zinc is weaker than that by potassium.

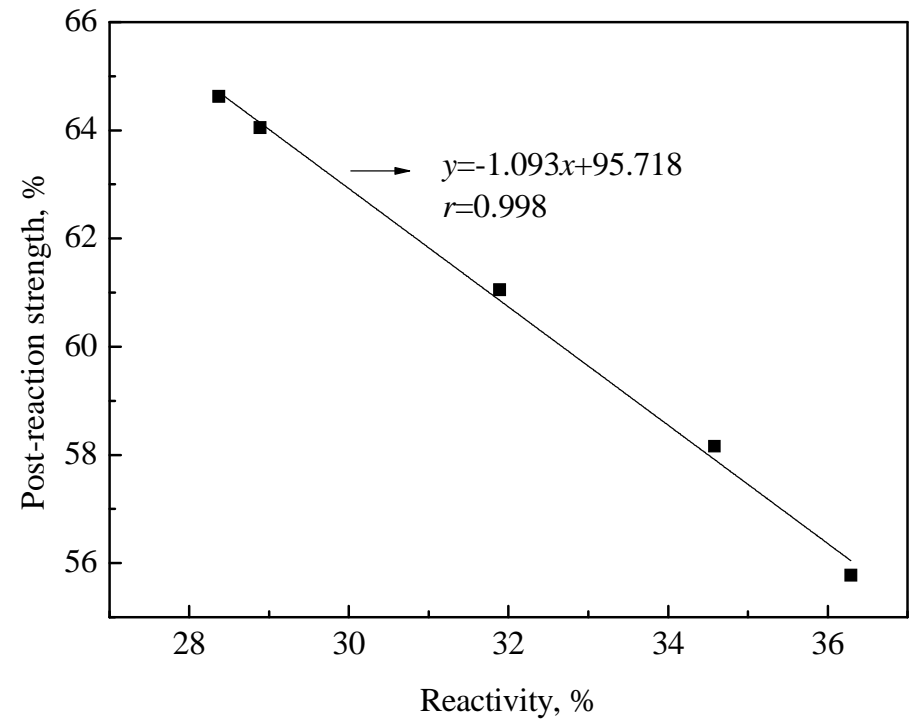

Fig. 4 Relationship between reactivity and post-reaction strength of ferro-coke with $\mathrm{ZnO}$ addition

According to GRIGORE ${ }^{[13]}$ et al. and REID et al., ${ }^{[14]}$ metallic iron and minerals in crystalline phases containing $\mathrm{Fe}, \mathrm{Ca}, \mathrm{K}$ and $\mathrm{Na}$ in the coke ash have catalytic effects on coke gasification. Zinc is usually listed in the category of transition elements and it is thus expected also having catalytic effect on ferro-coke gasification. The mechanism of this catalytic effect would be the promotion of oxygen transfer through $\mathrm{ZnO}$ and also the occurrence of $\mathrm{ZnO}+\mathrm{C}=\mathrm{Zn}+\mathrm{CO}$ reaction, increasing the porosity of ferro-coke. 


\section{CONCLUSIONS.}

(1) $\mathrm{Zn}$ has a catalytic effect on gasification of ferro-coke in respect to decreasing the starting gasification temperature and increasing the burning-off degree, and this catalytic effect is stronger when $\mathrm{ZnO}$ addition is below $0.85 \%$.

(2) $\mathrm{ZnO}$ addition has an effect of increasing the reactivity index $\mathrm{CRI}_{\mathrm{TCM}}$ and decreasing the post-reaction strength index $\mathrm{CSR}_{\mathrm{TCM}}$, but its effect is not as strong as potassium.

\section{ACKNOWLEDGEMENTS}

The National Natural Science Foundation of China (NFSC) provided financial support to this work (Project No.: 51174149). The authors are grateful to Mr. Teng YING and Shang-guo LIANG of the Wuhan Iron and Steel Company, Ltd. for invaluable advices and help during the study.

\section{References}

1) S. Gupta, B. C. Kim, M. Grigore, D. French, R. Sakurovs and V. Sahajwalla: Proc., Iron \& Steel Technology Conf. and Exposition (AISTech 2007), AIST, Warrendale, PA, (2007), p. 101.

2) A. Sharma, K. Uebo and Y. Kubota: Tetsu-to-Hagané, 96 (2010), p. 280.

3) M. Naito, A. Okamoto, K. Yamaguchi, T. Yamaguchi and Y. Inoue: Tetsu-to-Hagané, 87 (2001), p. 357.

4) S. Nomura, S. Matsuzaki, M. Naito, H. Ayukawa, S. Koizumi, Y. Ogata, T. Nakayama, T. Abe, H. Kitaguchi and T. Tahara: Proc., Iron \& Steel Technology Conf. and Exposition (AISTech 2006), AIST, Warrendale, PA, (2006), p. 31.

5) S. Nomura, H. Terashima, E. Sato and M. Naito: ISIJ Int., 47 (2007), p. 823.

6) M. Sato, H. Matsuno and K. Ishii: Proc. Asia Steel Int. Conf. 2015, The Iron and Steel Institute of Japan, Tokyo, (2015), p. 6A-1L1.

7) A. K. Biswas: Principles of Blast Furnace Iron Making, Cootha Publishing House, Brisbane, Australia, (1981), p. 249.

[8]Y. Yamaoka, A. Rist, J. B. Guillot, M. Schneider, P. Crecpin, J.L. Lebonvallet: Tetsu-to-Hagne, 1978: S114.

[9]S. Taguchi, T. Koitabashi, N. Tsuchiya and H. Takahashi: Tetsu-to-Hagne, 1982, No. 15: p. 282.

[10]K. Li, R. Khanna, J. Zhang, Z. Liu, V. Sahajwalla, T. Yang, D. Kong: Fuel, 133(2014), p. 194.

[11] P. Li, X. Bi, S. Shi, H. Zhang and J. Zhou: Journal of Iron and Steel Research, 27 (2015), p. 10.

[12]P. Li, W. Liu, H. Zhang, X. Bi, Y. Wang, J. Zhou, S. Shi: ISIJ Int., 57 (2017), 1-8 (to be published).

[13]M. Grigore, R. Sakurovs, D. French and V. Sahajwalla: ISIJ Int., 46 (2006), p. 503.

[14]M.H. Reid, M.R. Mahoney and B.J. Monaghan: ISIJ Int., 54 (2014), p. 628. 